【カテゴリーI】

\title{
高強度化軽量気泡繊維補強コンクリートの破壊特性 \\ FRACTURE PROPERTIES OF HIGH-STRENGTH LIGHT-WEIGHT AERATED FIBER REINFORCED CONCRETE
}

\author{
橘高 義典*, 高橋仁智**, 吉岡昌 洋** \\ Yoshinori KITSUTAKA, Yoshinori TAKAHASHI and Masahiro YOSHIOKA
}

\begin{abstract}
The fracture properties of high-strength light-weight aerated fiber reinforced concrete (HLAFRC) were investigated. Optimum mixing condition of HLAFRC which consists of the high-strength paste matrix, the short cut fiber, the entrained air and the artificial light-weight aggregate, was clarified. Three-point bending tests on pre-notched beam specimen of HLAFRC were performed. Fracture parameters of specimen were analyzed based on the poly-linear approximation analysis of tension softening diagram by using the data of a load-load point displacement curve. In this investigation, very ductile concrete of about 1 specific gravity with $20 \mathrm{MPa}$ compressive strength was obtained. The compressive strength and fracture energy of HLAFRC decreased with increase of the volume content of entrained air. The toughness of HLAFRC was significantly improved by mixing short cut fibers.
\end{abstract}

Keywords : fracture parameters, high-strength light-weight aerated fiber reinforced concrete, recycle materials, short cut fiber, fracture mechanics, tension softening diagram 破壊パラメータ, 高強度化軽量気泡䋐維補強コンクリート, リサイクル材料, 短綫維, 破壊力学, 引張軟化曲線,

\section{1.はじめに}

コンクリートの重要な構成材料である骨材に関して, その枯渴化， 低品質化，環境破壊，リサイクル性などが大きな問題となっている。 また，高強度化が大きく進む近年のコンクリートにおいては，べー ストに対する粗骨材強度は相対的に低く，欠陷部としての要素が強 くなり，従来のコシクリートのような応力伝達の主体という骨材の 機能は見いだしにくくなっている。一方で，粗骨材を含まない高強 度モルタルにより小断面・高強度の部材を作製することは可能であ るが, 一建築部材としての機能から見ると, “剛性の確保, 破壊時の工 ネルギーの吸収; 断熱性能などである程度の部材厚が必要となり， 小断面部材が必ずしも理想的とはならない。すなわち，部材容積を 確保するための内包物という機能が粗骨材にはある。近年の軽量骨 材の使用は, 高強度部材の軽量化という目的の他にも, 同一重量で 部材断面を厚くできるという容積効果にも着目すべきである。

このような容積効果としての骨材の機能を押し進めると，最も軽 量でかつ効率のよいものは空気泡ということになる。天然骨材の替 わりに独立気泡あるいは気泡を多く含む人工骨材を使用し, 高強度 ペーストマトリックスと組合わせることで，建築部材性能に優れる 効率的なコンクリート部材が得ら㧈る。特に，2次部材や增設耐震 壁などの軽量かつ部材厚が必要な部材への適用が考えら゙れる。

軽量気泡コンクリートの研究は古くから行わ扎数多くの成果が発
表されているがげ，強度の面で不十分であり，通常は特殊盖生を 必要とた。しかしながら現在の高強度化技術により常温での製造も 可能と考える。従って，特殊養生に要するエネルギーおよび天然粗 骨材が不要で省資源省エネルギーに対しても有利である。さらに, 空気泡とセメント系材料のみでは完全リサイクルも可能となる。一 方で，気泡を゙含むコンクリートにおいては，収縮，ひび割れ，引張 に対する勒性などについての性能低下が危惧されるが，この点につ いては短絨維混入などによる勒性向上が有効と考えられる(図一 1)。 本研究では，高強度ベースト中に，空気泡，人工軽量骨材，短瀻 維等を混入した高強度化軽量気泡絨維補強コンクリートについて, その破壊特性を実験検討した。各種試験体の切欠き梁 3 点曲げ試験 を行い, 荷重一荷重点変位曲線を計測し, 引張軟化曲線の逆解析結 果に基づき破買パラメータを算出し, マトリックス強度, 空気量, 短繊維長などが破壇バラメーダに及ぼす影響を考察した。

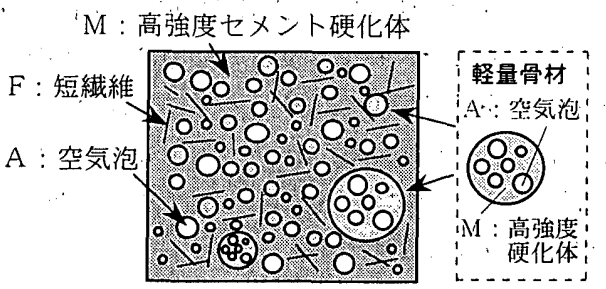

図-1高強度化軽量気泡纎維補強コンクリートの概念図

\footnotetext{
* 東京都立大学大学院工学研究科建築学尃攻 助教授. 工博

** 東京都立大学大学院工学研究科建築学専攻 大学院生
}

Assoc. Prof., Dept. of Architecture and Building Science, Graduate School of Eng., Tokyo Metropólitan Univ., Dr. Eng.

Graduate Student, Dept. of Architecture, Graduate School of Eng., Tokyo Metropolitan Univ. 


\section{2. 実験概要}

\section{1 試験体の概要}

表ー1 に使用材料を示す。セメントには 2 次部材への適用を考慮 し早強ポルトランドセメントを用いた，細骨材には比重が比較的小 さいガラス廃材による発泡人工軽量骨材（最大径 $5 \mathrm{~mm}, 1$ 号: 2 号： 3 号 $=8: 1: 1$ (質量比)）を用い, 混和剂には高性能 $\mathrm{AE}$ 減水剂及 び A E 剤を使用した。起泡刻にはアニオン系特殊界面活性剤を使用 した。短織維は，既報 ${ }^{3)} よ り$ 高強度モルタルの勒性改善効果に有効 であると考察されたビニロン繊維を選定し，その容積混入率は $1 \%$ とし，繊維長の影響を見るために $15 \mathrm{~mm}$ と $30 \mathrm{~mm}$ の 2 種類とした。 ベースト強度の影響を見るため，水結合材比（W/B）を $20 \%$ （記 号 $\mathrm{H}$ ）と $30 \%$ （記号 M）の 2 水準とし，前者にはシリカフューム を混入した。気泡を導入する試験体の起泡剤の添加量は予備実験結 果より粉体質量の $0.5 \%$ とし，添加無しの試験体と比較した。表 -2 に試験体の調合条件を示す。なお，予備実験において，W $/ \mathrm{B}=20 \%$, 緎維長 $=30 \mathrm{~mm}$ の条件で, 起泡㓮の添加量を $0,0.25,0.50,0.75$ (\%) の 4 段階に設定し, 起泡剤の添加量之試験体の比重及び空気量との 関係を求め, 最も空気連行量が多くなる起泡刘添加量を求めること とした。

試験体の練混ぜには二軸強制練りミキサーを使用し，空練りを 30 秒間行い, 加水して 90 秒間, 起泡剤を添加し混練後, 短繊維を少 しずつ投入しながら計 7 分間の混練を行った。圧縮強度試験用供試 体の寸法は $\phi 100 \times 200 \mathrm{~mm}$, 破壊勒性試験用の曲げ試験体の寸法は $100 \times 100 \times 450 \mathrm{~mm}$ とし，各条件につき 3 本ずつ作製した。なお， 空気量の計測に関し $10 \%$ 上のものは試験体作製時の単位容積質量 及び調合から換算し求めた。試験体は打設後 2 日で脱型し，その後 $20^{\circ} \mathrm{C}$ 水中で材龃 8 週まで養生した。表一 3 に各試験体のフレッシ ユコンクリートでの性状及び硬化後の圧縮強度を示す。

\section{2 破壞特性の評価}

試験体の破壊特性を評価するために RILEM 法 》に準じた切欠き 梁の 3 点曲げ試験を行った。試験体寸法は $100 \times 100 \times 450 \mathrm{~mm}$ で 中央にダイヤモンドカッター（刃厚 $1 \mathrm{~mm}$ ）により, 梁せいの半分 $(50 \mathrm{~mm})$ の切欠きを入れた。支持点スパンは $400 \mathrm{~mm}$ とした（ス バンはりせい比 4)。試験装置には, 図ー2 に示すクローズドルーブ システム（閉回路機構）を有するサーボ・コントロール式油圧試験 機（MTS 社製）を用いた。切欠き端部のひび割れ開口变位 (CMOD) を高感度クリッブゲージ（MTS-632.02）により計測し開口変位速 度を制御した。開口変位速度は安定破壊が得られるよう織維無混入 試験体では $0.02 \mathrm{~mm} / \mathrm{min}$, 繊維混入試験体では $0.04 \mathrm{~mm} / \mathrm{min}$ と した。さらに 2 本の変位計により荷重点変位を計測し, 引張軟化曲 線解析用のデータとした。荷重点変位の計測には, 特性のアタッチ メントを使用し，計測精度を上げるとともに变位計のセッティング を簡便にした。また，変位計は試験体に固定した治具に取りつけ， 試験体載荷部のめりこみによる変位計の誤差を取り除いた。図ー3 に試験体および変位計の取付け概要を示す。

切欠き梁の 3 点曲げ試験より得ら扟る荷重一荷重点变位曲線を基 に, 多直線近似法 ${ }^{5)}$ により引張軟化曲線（破壊進行領域を結合力モ デルにより仮想ひび割れでモデル化したときでの結合力とひび割れ 開口変位との関係, TSD と略す) を求めた。本解析法は, ひび割れ 進展解析を進めながら多直線型の TSD を逐次最適化し求めるもの
表 -1 使用材料

\begin{tabular}{|c|c|c|}
\hline 钎号 & 材 料 & 性 㬴 \\
\hline $\mathrm{C}$ & セメント & 早強ボルトランドセメント 比重 3.20 \\
\hline $\mathrm{SF}$ & シリカフューム & $\mathrm{SiO}_{2} 96.8^{\circ} \mathrm{o}$ 比重 2.20 \\
\hline $\mathrm{VF}$ & $\begin{array}{l}\text { ビニロン織維 } \\
(R F 1500)\end{array}$ & 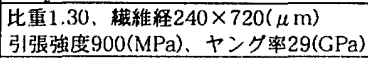 \\
\hline $\mathrm{CL}$ & 発泡ガラス肾材 & 1 岇: 2 岁 $: 3$ 岇 $=8: 1: 1$ 、比重 0.70 \\
\hline $\mathrm{SP}$ & 高性能AE琙水剛 (SP8HE) & ポリカルボン酸エーテル系 \\
\hline $\mathrm{AE}$ & AE用 (MA303A) & アルキルアリルスルホン酸化合物系 \\
\hline $\mathrm{FA}$ & 起泡戍 (FA200) & アニオン系特殊界面活性剂 \\
\hline
\end{tabular}

表一2 試験体の計画調合

\begin{tabular}{|c|c|c|c|c|c|c|c|c|c|c|c|}
\hline \multirow{3}{*}{$\begin{array}{l}\text { 記 } \\
\vdots j\end{array}$} & \multirow{3}{*}{$\begin{array}{c}W \\
\mathrm{~B} \\
(\%)\end{array}$} & \multirow{3}{*}{$\begin{array}{l}\text { 添起 } \\
\text { 溜 } \\
\text { 量 剂 } \\
(\%) \\
\text { (\%) }\end{array}$} & \multirow{3}{*}{$\begin{array}{c}\text { 緎 } \\
\text { 維 } \\
\text { 主 } \\
(\mathrm{mm}) \\
\end{array}$} & \multicolumn{8}{|c|}{ 計画調合 $\left(\mathrm{kg} / \mathrm{m}_{3}\right)$} \\
\hline & & & & \multirow{2}{*}{$\begin{array}{l}\text { 水 } \\
\mathrm{W}\end{array}$} & \multirow{2}{*}{ 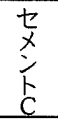 } & \multirow{2}{*}{$\begin{array}{l}\text { 骨 } \\
\text { 材 } \\
\text { GL }\end{array}$} & \multirow{2}{*}{$\begin{array}{l}\text { 混 } \\
\text { 晳 } \\
\text { 材 } \\
\text { SF }\end{array}$} & \multicolumn{3}{|c|}{ 沙和戍 } & \multirow{2}{*}{$\begin{array}{l}\text { 瀻 } \\
\text { VF } \\
\text { VF }\end{array}$} \\
\hline & & & & & & & & $\mathrm{SP}$ & FA & $\mathrm{AE}$ & \\
\hline \multirow{4}{*}{$\begin{array}{l}\mathrm{HO} \\
\mathrm{H} 15 \\
\mathrm{H} 30 \\
\mathrm{HAO}\end{array}$} & \multirow{6}{*}{20} & \multirow{3}{*}{-} & & 150 & 677 & \multirow{12}{*}{420} & 75 & 30.1 & - & 4.5 & - \\
\hline & & & 15 & 147 & 660 & & 73 & 29. & - & 4.4 & 13.0 \\
\hline & & & 30 & 147 & 660 & & 73 & 29.3 & - & 4.4 & 13.0 \\
\hline & & \multirow{3}{*}{0.5} & - & 150 & 677 & & 75 & 30 & 3.8 & 4.5 & - \\
\hline HA15 & & & 15 & 147 & 660 & & 73 & 29. & 3.7 & 4. & 13.0 \\
\hline & & & 30 & 147 & 660 & & 73 & 29.3 & 3.7 & 4.4 & 13.0 \\
\hline & \multirow{6}{*}{30} & \multirow{3}{*}{-} & - & 194 & 647 & & - & 6. & - & 3.9 & - \\
\hline & & & 15 & 189 & 631 & & $=$ & 6.3 & $=$ & 3.8 & 13.0 \\
\hline \multirow{4}{*}{$\frac{\text { M30 }}{\frac{\text { MAO }}{\text { MA15 }}}$} & & & 30 & 189 & 631 & & $=$ & 6. & - & 3.8 & 13.0 \\
\hline & & \multirow{3}{*}{0.5} & - & 194 & 647 & & - & 6.5 & 3.2 & 3.9 & . \\
\hline & & & 15 & 189 & 631 & & $=$ & 6.3 & 3.2 & 3.8 & 13.0 \\
\hline & & & 30 & 189 & 631 & & $=$ & 6.3 & 3.2 & 3.8 & 13.0 \\
\hline
\end{tabular}

表 -3 試験体の性状

\begin{tabular}{|c|c|c|c|c|c|}
\hline $\begin{array}{l}\text { 記 } \\
\text { 号 }\end{array}$ & $\begin{array}{c}\text { 조 } \\
\text { シ } \\
\text { ᄀ゙ } \\
(\mathrm{cm})\end{array}$ & 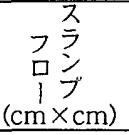 & $\begin{array}{l}\text { 比 } \\
\text { 重 }\end{array}$ & $\begin{array}{l}\text { 空* } \\
\text { 気 } \\
\text { 量 } \\
\text { (\%) } \\
\end{array}$ & $\begin{array}{c}\text { 压 } \\
\text { 縮 } \\
\text { 强 } \\
\text { (Mpa) } \\
\end{array}$ \\
\hline $\mathrm{HO}$ & 28.5 & $80 \times 79$ & 1.31 & 3.5 & 32.6 \\
\hline $\mathrm{H} 15$ & 25.0 & - & 1.35 & 0.0 & 38.6 \\
\hline $\mathrm{H} 30$ & 18.6 & - & 1.32 & 2.3 & 37.1 \\
\hline $\mathrm{HAO}$ & 27.0 & $54 \times 56$ & 0.86 & 36.6 & 11.2 \\
\hline HA15 & 26.5 & $47 \times 50$ & 0.89 & 33.7 & 18.5 \\
\hline HA30 & 26.5 & $49 \times 50$ & 0.87 & 35.4 & 12.8 \\
\hline MO & 26.5 & - & 1.17 & 9.3 & 26.1 \\
\hline M15 & 21.9 & $=$ & 1.21 & 5.9 & 29.5 \\
\hline M30 & 22.1 & - & 1.21 & 6.0 & 29.5 \\
\hline $\mathrm{MAO}$ & 26.0 & $48 \times 48$ & 0.85 & 34.5 & 9.7 \\
\hline MAI5 & 25.5 & $50 \times 52$ & 0.83 & 36.0 & 7.5 \\
\hline MA30 & 25.5 & $48 \times 48$ & 0.83 & 35.4 & 7.9 \\
\hline
\end{tabular}

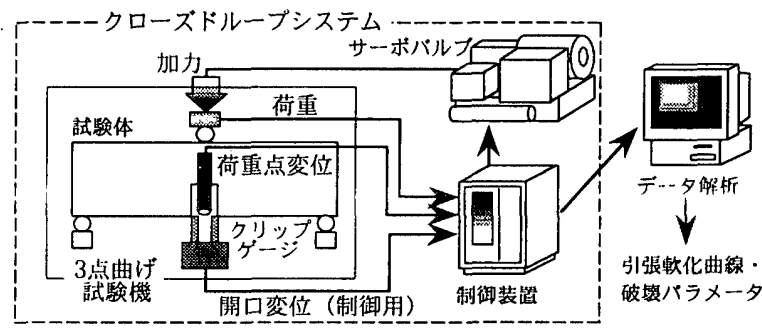

図-2 システムフローチャート

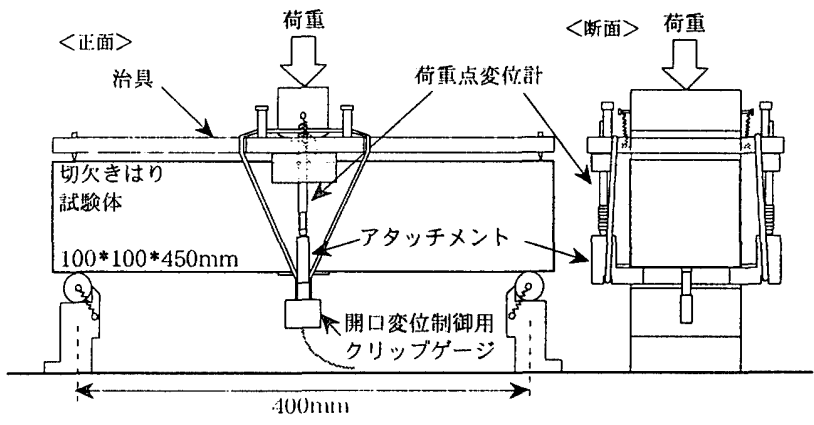

図-3 試験体および変位計取付け概要 
である ${ }^{5)}$ 。なお, 瀻維補強の場合, 変形量が大きくなると梁上部縁 が圧壊となる可能性も考えられるが，圧縮域は線形弾性と仮定し引 張軟化曲線を求めた。また，TSD で囲まれた面積は，破壊時に消費 されるエネルギーの評価値となるが，緎維補強コンクリート等の非 弾性変形が大きな材料では，完全な破断に至らず限界開口変位の評 価が難しいため, 開口変位 $0.5 \mathrm{~mm}$ までの面積を有効破壊エネルギ

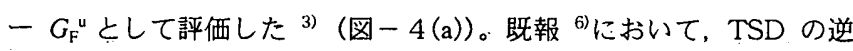
解析の過程より算定される結合力モデルでのエネルギ一解放率 $G_{p} に$ より，破壊進展に伴うエネルギー消費，すなわちひび割れ進展抵抗 性を精度良く評価できることが明らかにされている。そこで， $G_{p}$ と 切欠き端部のひび割れ開口変位（CMOD）の関係をブロットし， 破壊進展に伴うひびわれ進展抵抗性を評価した。ここで $G_{p}(\mathrm{~N} / \mathrm{m})$ は, 結合力モデルにおいて単位ひび割れ進展 $d a$ 当たりに結合力 $\sigma(\delta)$ の成した仕事である(式 (1)，図ー4(b)参照)。

$$
G_{p}=\frac{d}{d a} \int_{a_{0}}^{a} \sigma(\delta) \cdot \Delta \delta d x
$$

\section{3. 実験結果および考察}

3.1 起泡剤添加量と比重及び空気量との関係

図-5に予備実験で求めた起泡剂添加量と比重及び空気量との関 係を示す。なお，ここでの比重はコンクリート打設時での単位容積 質量とした。起泡剤添加量が $0.5 \%$ までは添加量の增加に伴い比重 は低下する。起泡剤添加量 $0.5 \%$ 以上では横追いとなり，それ以上 の添加に見合う気泡導入効果は得られないことより，本実験での起 泡剤添加量は $0.5 \%$ とした。今回の材料条件により起泡剮添加量 $0.5 \%$ で約 $35 \%$ の空気連行量が得ら扎た。 なお，各調合条件でのフ レッシュコシクリートは, 表ー 3 のスランブ値及びフロー値に示す ように; 適度な流動性を有し骨材の分離は見られなかった。すなお ち, 従来の軽量骨材コンクリートにおいては、フフレッシュ時での骨 材の浮き分離が問題となるが，気泡を導入することでペーストマト リックスが低比重となり軽量骨材との比重差が小さく，分離が生じ にくくなるものと考えられる。

\section{2 比重及び空気量と圧縮強度との関係}

図一6.に，圧縮強度と比重及び空気量との関係をそれぞれ示す。 比重が大きくなるほど圧縮強度は大大きくなり，両者はほぼ比例関係 にある。これは図ー6. 右に示すようฺに，比重が小さいものは空気量 が多く，准部が増加し全体の強度が低下するためである。本実験 条件により比重約 1 で約 $20 \mathrm{MPa}$ の圧縮強度が得られた。

\section{3 荷重一荷重点変位曲線}

図ー7 に切欠き梁 3 点曲げ試験で得られた荷重一荷重点変位曲線 （以下，LPD 曲線）を調合条件別に示す。図中には同一条件での 3 本の LPD 曲線を平均化したものを示した。全ての試験体条件にお いて安定した LPD 曲線が得られた。全体的に，起泡㓮の混入によ り最大荷重は小さくなる傾向を示す。これは，空気泡の増加により 欠楩部が增し応力を伝達する有効面積が低下することが主な理由と 考えられる。

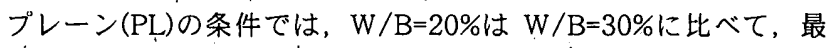
大荷重は大きいが最大荷重以降の下降度も大きく脆性的となる。こ

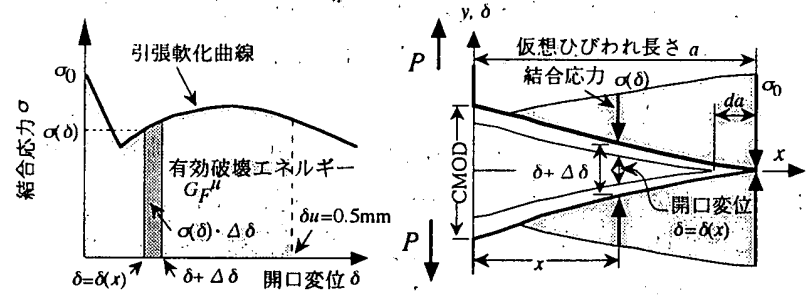

a)引張軟化曲線

b）結合力モデルでのエネルギー変化

図-4.引張軟化曲線とエネルギー变化



図-5 起泡郕添加量と比重及び空気量の関係


図-6 圧縮強度と比重及び空気量の関係
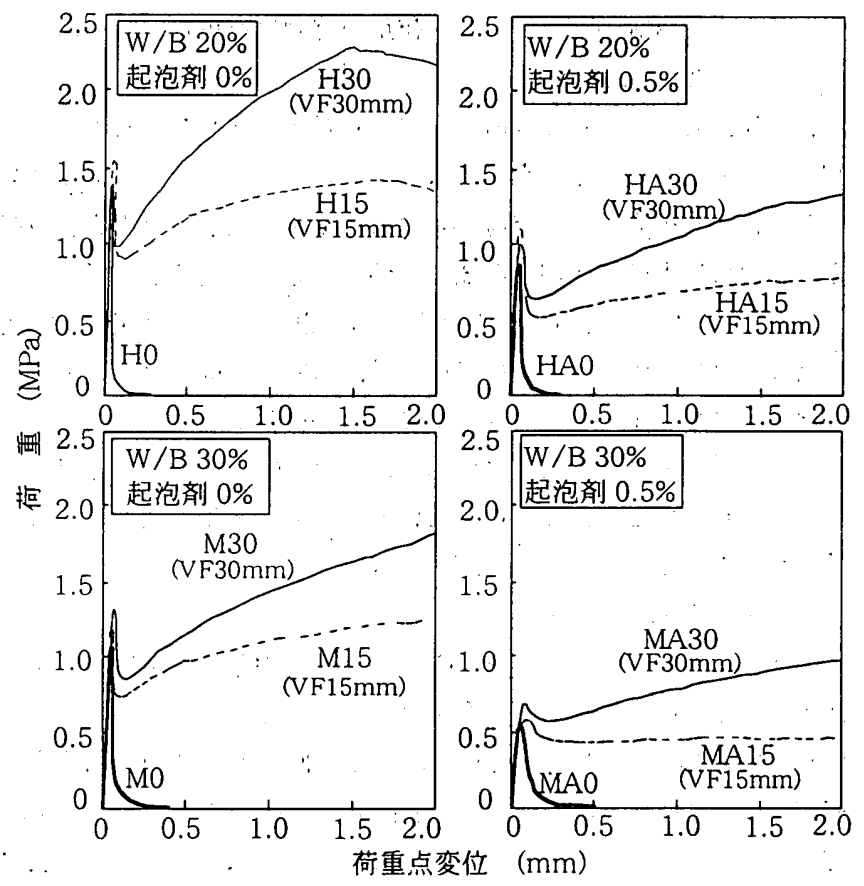

図-7. 荷重一荷重点变位曲線（平均化） 
の理由として，ペースト強度が増加するほど相対的に軽量骨材の強 度が低下し，骨材部が欠陥となりひび割れが伝達しやすくなること が考えられる。

また，W/B=20\%，W/B=30\%とも短織維（VF）を混入すること により，最初の荷重ピーク直後に一旦荷重が低下するが，その後再 び荷重が増加する硬化現象を示し，勒性が大きく向上している。起 泡剤添加の試験体についても同様である。荷重変位曲線の上昇の程 度は, $\mathrm{W} / \mathrm{B}=20 \%$ が $\mathrm{W} / \mathrm{B}=30 \% に$ 比べて大きくなっており，繊維混 入(VF)の場合にはブレーン(PL)とは逆に高強度のベーストの方が勒 性能に優孔る。この理由は，ペースト強度が大きいほど，繊維の付 着強度が大きく，瀻維の引き抜けに対する抵抗力が大きくなり勒性 が向上するためと考えられる。また, 繊維長が $15 \mathrm{~mm}$ よりも $30 \mathrm{~mm}$ の方が曲線で囲まれた面積は大きくなり勒性能に優れる傾向にある。 この理由は，繊維混入量が同一であっても繊維長が長いほど，一本 の緎維表面とペーストとの付着面積が大きく，引抜けに対する伝達 力が大となり，ひび割れ進展に対する抵抗力が増加するためと推察 される。

\section{4 引張軟化曲線}

図ー8に LPD 曲線から多直線近似解析によって求めた引張軟化曲 線（TSD）を示す。初期の変化を比較しやすいように開口変位 0.1 mmまでを示した。TSD は LPD 曲線を反映しており，LPD 曲線で 勒性に優れるものは TSD の軟化度が緩やかで，TSD で囲まれた面 積も大きくなる。また, 繊維混入試験体 (VF) においては一時的に 横這いあるいは右上がりとなる引張硬化の傾向がみられる。

特徵的なことは，一部の緎維混入試験体では初期の軟化により結 合応力が 0 近くとなり，その後, 結合応力が增加している点である。 この理由として, 初期の軟化性状はモルタルマトリックスの性状を 反映するため, 特にモルタルの破塄が脆性的な場合には, 瀻維のブ リッジング作用が有効に生じる開口変位に達する以前に，モルタル が限界ひび割れ開口変位に達してしまい伝達応力がほぼ 0 近くとな り，その後，緎維のブリッジング作用が有効に作用し応カが伝達さ れていくことが考えられる。

各条件において，起泡剤の添加により材料の本質的な引張強度に 相当する初期結合応力は大きく低下する。この理由は応力伝達に有 効な面樻が減少するためと考えられる。しかしながら，T S D の初 期の軟化の程度は起泡㓮無添加の条件よりもやや緩くなり延性的に なっている（例えば M0 と MA 0 )。この理由として, 空気泡の存在 により，ひびわれが平面的に進展せず，偏向し分散しながら複雑に 進展し，エネルギーの消費量を增加させていることが考えられる。 また，繊維混入により初期結合応力は大きくは増加せず，無混入と ほほ変わらないことより，初期結合応力はモルタルマトリックスの 特性を反映していると考えられる。

\section{5 有効破壊エネルギー}

図-9に, 各条件での有効破壊エネルギー $\left(G_{\mathrm{F}}{ }^{\mu}\right)$ の平均值と比重 及び空気量との関係を示す。綫維無しの試験体（図ー9上）では, $\mathrm{W} / \mathrm{B}=20 \%$ では空気量が多い方が $G_{\mathrm{F}}{ }{ }$ はやや低下する。しかしながら， 圧縮強度に見られるような大きな低下度ではない。また，W/B=30\% では空気量増加によっても $G_{\mathrm{F}}{ }{ }^{\prime}$ はあまり変わらない。これらの理由 は図-8 でも考察したように，空気泡の存在により破壊が延性的に なるためと考えられる。
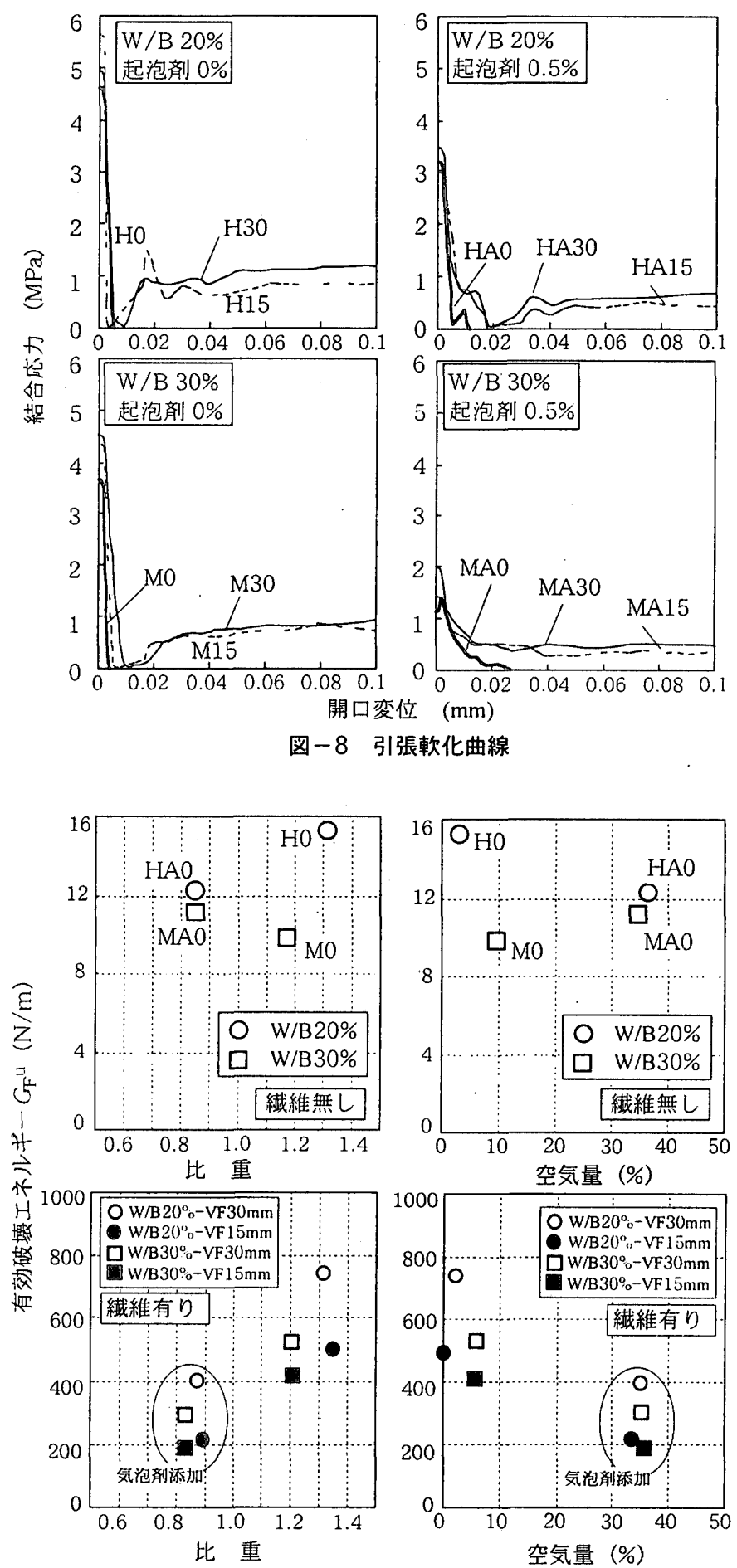

図-9 有効破壊エネルギーと比重及び空気量との関係

繊維補強試験体（図一-9下）においては，各試験体とも空気量の 増加によって $G_{\mathrm{F}}{ }{ }^{*}$ は低下する。これは, 空気泡の存在により織維と ペーストとの付着面積が低下し, エネルギー吸収が小さくなるため と考えられる。しかしながら，䄉維無しの試験体に比べると大きな エネルギー吸収を示しており, 織維混入による勒性向上効果は大き い。また, 各試験体において繊維長 $15 \mathrm{~mm}$ （黒塗り）に対し $30 \mathrm{~mm}$

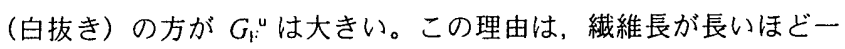
本の䋐維のペーストとの付着面積が大きく, 引抜けに対する伝達力 が大となるためと考えられる。 

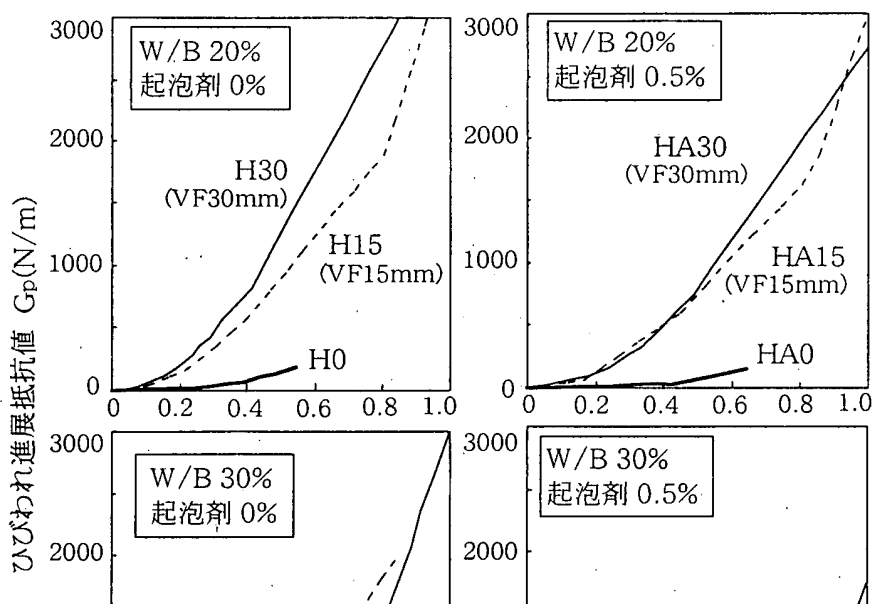

M15

1000

$$
\text { (VF15mm) }
$$
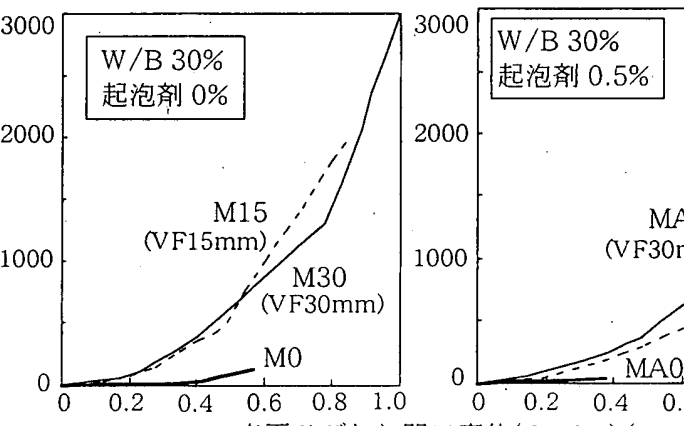

2000

表面ひびわれ開口変位 $(\mathrm{CMOD})(\mathrm{mm})$

図-10 ひびわれ進展抵抗曲線

\section{6 ひび割れ進展抵抗曲線}

図-10 に表面ひびわれ開口変位（CMOD）とひび割れ進展抵抗 值 $G_{\mathrm{p}}$ の関係（Rカーブ）を示す。本図より破壊進展に要するエネ ルギーの変化を考察すると以下のようである。䋐維無しの試験体は ひび割れに対する抵抗が小さく脆性的な破壊形態を示すといえる。 それに対して繊維混入の試験体は初期の抵抗力は瀻維無しの試験体 と同様低いが，ひび割れが進展するにつれてグラフは右上がりの傾 向を示し急激に勒性が向上する。この上昇は繊維のブリッジング作 用によるものと考えられる。各繊維混入試験体とも $W / B=20 \% の$ 方

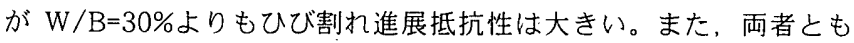
起泡剤の添加によりひび割れ進展抵抗性は低くなる。纎維長 $30 \mathrm{~mm}$ と $15 \mathrm{~mm}$ の試験体とでは, 表面開口変位 $1 \mathrm{~mm}$ 程度までのひび割れ 進展に対してはほぼ同じ抵抗力を示すが，30 $\mathrm{mm}$ の方がやや抵抗力 が大きい。

\section{4. まとめ}

高強度化軽量気泡繊維補強コンクリートに関し，ペースト強度， 起泡剤の添加, 繊維の有無, 繊維長などが, 諸物性及び勒性能に及 ぼす影響を検討した。その結果，今回行った実験の範囲で以下のこ とが明らかとなった。

（1）起泡剤添加量が增加するほど空気連行量は多くなるが，ある 添加量で空連行効果は頭打ちとなる。今回用いた起泡剤では結合材 質量 0.5\%の添加量で頭打ちとなり約 35\%の気泡量が得られた。

（2）気泡導入によりペーストマトリックスを低比重とすることで,
骨材との比重差を小さくでき骨材の材料分離を生じにくくすること が可能である。

（3）試験体の連行空気量が多くなるほど圧縮強度は小さくなり, 連行空気量約 35\%までの範囲で両者には反比例関係がある。

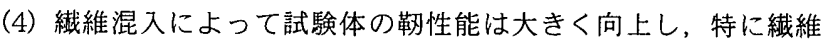
長が長い方が破壊に要するエネルギーは大きく，勒性能に優れる。

（5）試験体の空気量が増大するほど, 応力伝達の有効面積の低下 · 欠陥部の增加等により, 試験体の引張強度を支配する初期結合応力 は低下する。また, 初期結合応力はモルタルマトリックス自体の特 性に依存し，䋐維混入によっては大きくは增加しない。

（6）繊維無混入の試験体は脆性的な破壊を示すが, 空気量の增加 によって破壊エネルギーは大きくは低下しない。その理由として空 気泡の存在がひび割れの偏向作用を生じていることが考えられる。

（7）繊維混入の試験体は, 䋐維無混入の試験体に比べ大きな破壊 エネルギーを示し勒性に優れる。ただし, 空気量が増大するほど, 絨維のペーストとの付着面積低下などの理由により破買に要するエ ネルギーは低下する。

\section{謝 辞}

本研究を行うに当たり, 実験にご協力頂いた，東急建設（株）・大 岡督尚氏，ご助言頂いた（株）フジタ・青木治雄氏に深く感謝いた します。さらに, 試料を提供してくださった, 山宗化学（株）, 相武 生コン（株），クリスタルクレイ(株)，クラレ（株）、に感謝の意を 表します。な㧍，本研究の一部は文部省科学研究費（基盤C）の助 成を受けました。

\section{参考文献}

1）白山和久，上村克郎：「気沱コンクリート」，オーム社，1964

2）山本䐂弘，户祭邦之，山田哲夫他：高品質軽量気泡コンクリート（FＬC） の開発：大成建没技術研究所報，第 20 咢，pp.109-113

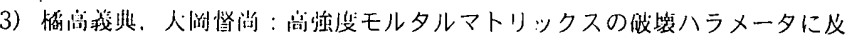

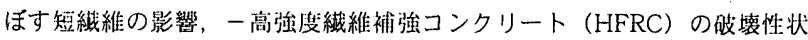
に関する研究一，日本建策学会構造系論文集，No.497，pp.1-8.1997.7

4) RILEM Draft Recommendation, Determination of the Fracture Energy of Mortar and Concrete by Means of Three-point Bend Test on Notched Beams, Materials and Structures, Vol.18, No.106, pp.285 $\sim 290,1985$

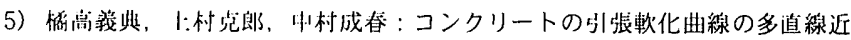

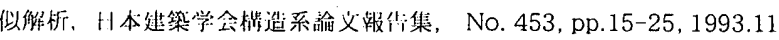

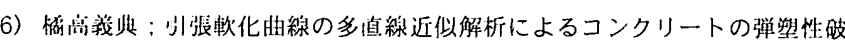

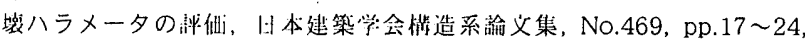
1995.3 